\title{
Anterior mediastinal mass due to thoracic splenosis
}

\author{
Jacqueline Soraru, ${ }^{1}$ Giuseppe Cardaci $^{2}$
}

${ }^{1}$ Sir Charles Gairdner Hospital, Perth, Western Australia, Australia

${ }^{2}$ Department of General Medicine, Hollywood Private Hospital, Perth, Western Australia, Australia

\section{Correspondence to} Dr Jacqueline Soraru, jackie. soraru@gmail.com

Accepted 8 March 2015

\section{DESCRIPTION}

An 81-year-old man was investigated for weight loss, fever, deranged liver enzymes and elevated inflammatory markers. CT imaging revealed a lobulated well-defined anterior mediastinal mass $(1.7 \times 2.8 \times 3.2 \mathrm{~cm})$ and a further small $(1.43 \times 0.59 \times 1.9 \mathrm{~cm})$ subpleural nodule in the left posterior thorax. The possibility of mediastinal neoplasm was raised, with biopsy of the anterior mediastinal mass contemplated.
There was a history of blunt abdominal trauma 30 years prior, requiring surgical repair of a ruptured left hemidiaphragm, splenectomy and left nephrectomy. Considering this, a heat denatured red blood cell (RBC) study was performed. Tc-99m labelled autologous RBCs were warmed in a hot water bath to crenate but not lyse the cells, and were reinjected prior to SPECT-CT imaging. As the spleen functions to entrap and remove damaged RBCs, the heat-denatured RBC study is a

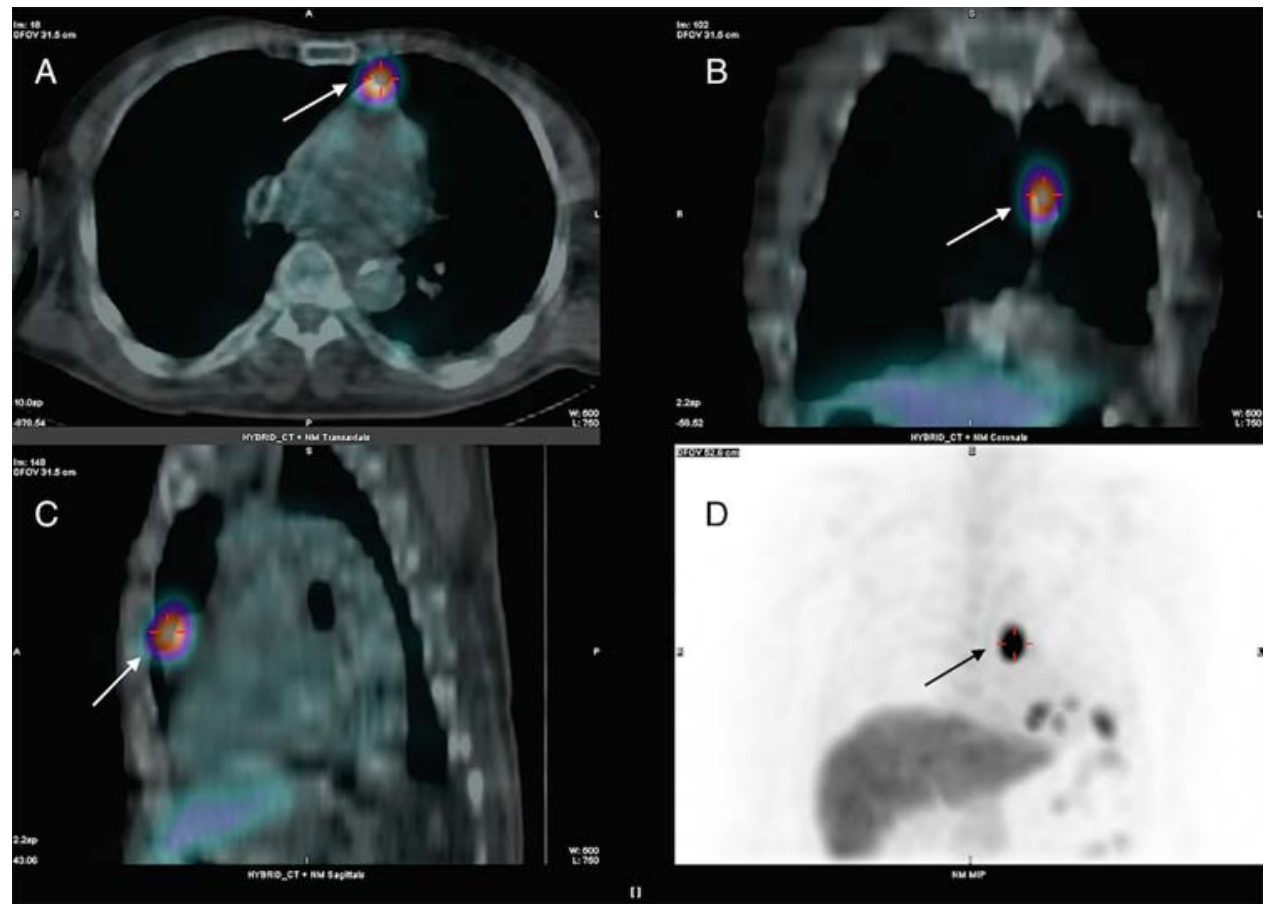

Figure 1 SPECT-CT images in (A) transverse section, (B) coronal section and (C) sagittal section, demonstrating uptake of Tc-99m labelled heat denatured red blood cells in the anterior mediastinal mass. Maximum intensity projection image (D) demonstrated predominant uptake in the anterior mediastinal mass as well as multifocal left upper quadrant and left hemithorax foci.

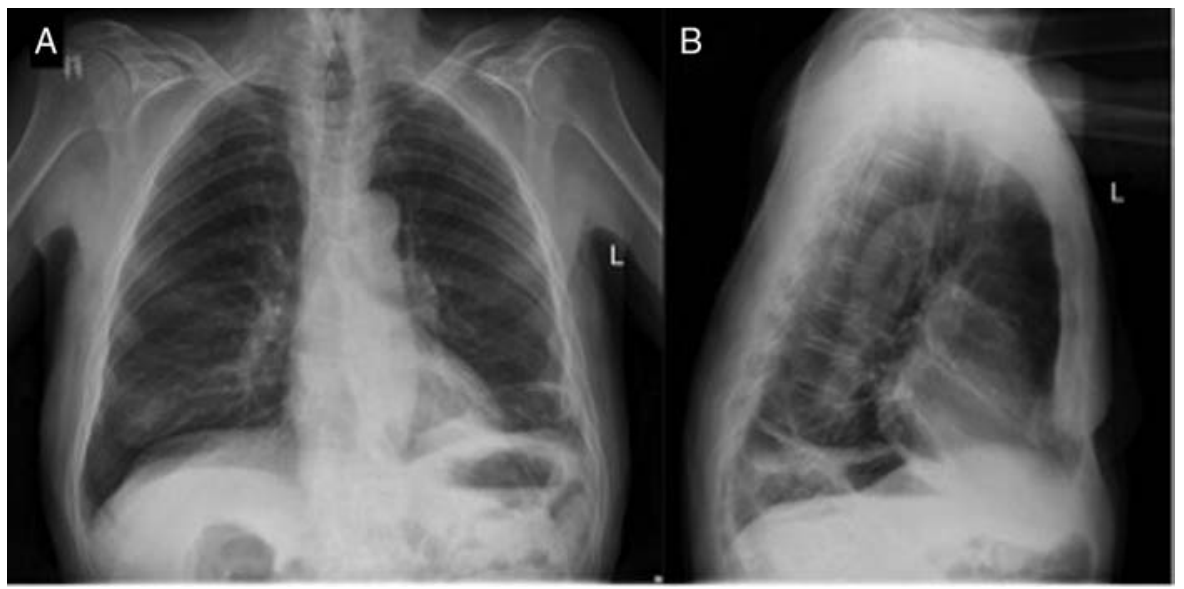

Figure 2 A chest X-ray in (A) anteroposterior and (B) lateral views, taken 4 months after diagnosis of the thoracic splenosis with normal mediastinal contour. 
very sensitive and specific method of identifying splenic tissue. ${ }^{1}$

The study demonstrated intense localisation of the labelled RBCs within the anterior mediastinal mass, with several less intense foci of uptake subpleurally in the left hemithorax and left upper quadrant of the abdomen (figure 1). These findings

\section{Learning points}

- This is the first known report of anterior mediastinal splenosis following splenic rupture after abdominal trauma.

- Diagnosis of thoracic splenosis can be made using denatured radiolabelled red blood cell (RBC) scans. The viable but crenated $R B C s$ are rapidly cleared from the circulation by splenic tissue, making the test highly sensitive and specific in identifying splenic tissue.

- Fusion SPECT-CT imaging allows for accurate anatomic localisation of lesions in nuclear medicine studies. are characteristic of splenosis, with a prominent anterior mediastinal rest of splenic tissue. Biopsy of the anterior mediastinal mass was averted. Low grade ascending cholangitis secondary to choledocholithiasis was thought to account for symptoms. Follow-up chest X-ray demonstrated normal mediastinal contours (figure 2).

Thoracic splenosis has been previously reported,,$^{2}$ but this is the first report, to our knowledge, of splenic tissue presenting as an anterior mediastinal mass.

Competing interests None.

\section{Patient consent Obtained.}

Provenance and peer review Not commissioned; externally peer reviewed.

\section{REFERENCES}

1 MacDonald A, Burrell S. Infrequently performed studies in nuclear medicine: part 1. J Nucl Med Technol 2008;36:132-43.

2 Crivellaro C, Cabrini G, Gay E, et al. Intrathoracic splenosis: evaluation by 99mTc-labelled heat-denatured erythrocyte SPECT/CT. Eur J Nucl Med Mol Imaging 2011;38:412.

3 Mancano AD, Zanetti G, Duarte BC, et al. Thoracic splenosis after thoracoabdominal trauma presenting as pleural nodules. Lung 2012;190:699-701.

Copyright 2015 BMJ Publishing Group. All rights reserved. For permission to reuse any of this content visit

http://group.bmj.com/group/rights-licensing/permissions.

BMJ Case Report Fellows may re-use this article for personal use and teaching without any further permission.

Become a Fellow of BMJ Case Reports today and you can:

- Submit as many cases as you like

- Enjoy fast sympathetic peer review and rapid publication of accepted articles

- Access all the published articles

- Re-use any of the published material for personal use and teaching without further permission

For information on Institutional Fellowships contact consortiasales@bmjgroup.com

Visit casereports.bmj.com for more articles like this and to become a Fellow 